\section{Occupational Safety, Health \& Environmental (SHE) Issues linked to Erosion of Systems and Replacement of Machines}

\author{
Talha Majeed Khan ${ }^{1}$, Qais Aslam²
}

The Journal of Educational Paradigms 2020, Vol. 02(02) 125-134

(C) Authors

ISSN (Print): 2709-202X

ISSN (Online): 2709-2038

DOI: $10.47609 / 0202032020$

\begin{abstract}
Managing market risk under unknown future shocks is a critical issue for policymakers, investors and professional risk managers. These shocks can be external to the firm, like demand conditions or conditions in the market as well as internal shocks like inefficiencies or issues of governance in a business entity. More important is the health of machines and viability of systems that are in place in a firm that might threaten the safety of the workforce, tend to take the organizational management towards expensive litigation and eroding in the future of its brand position. "According to recent estimates released by the International Labor Organization (ILO), each year 2.78 million workers die from occupational accidents and work-related diseases (of which 2.4 million are disease-related) and an additional 374 million workers suffer from non-fatal occupational accidents. It is estimated that lost workdays globally represent almost 4 percent of the world's GDP” (International Labor Organization (ILO), 2019) Problem statement A large number of firms in Pakistan are noncompliance of governance guideline especially in Safety, Health and Environment (SHE) and therefore the present study will take as SHE as its basis to investigate the future issues in the industrial sector of Pakistan.
\end{abstract}

Keywords: Occupational safety, Health \& Environmental, Erosion System, Replacement.

Managing market risk under unknown future shocks is a critical issue for policymakers, investors and professional risk managers. These shocks can be external to the firm, like demand conditions or conditions in the market as well as internal shocks like inefficiencies or issues of governance in a business entity. More important is the health of machines and viability of systems that are in place in a firm which might threaten the safety of the work force, tend to take the organizational management towards expensive litigation and eroding in the future of its brand position. "According to recent estimates released by the International Labor Organization (ILO), each year 2.78 million workers die from occupational accidents and work-related diseases (of which 2.4 million are disease-related) and an additional 374 million workers suffer from non-fatal occupational accidents. It is estimated that lost workdays globally represent almost 4 per cent of the world's GDP" (International Labor Organization (ILO), 2019).

Hazardous workplace and working environment are essential part of industrial activity due to the presence of hazard in their technology and processes. Presence of hazard creates risks of accidents and diseases to employees of the industry.

By the help of good governance and through dynamic leadership, SHE practices, and policies can be promoted, and risk can be mitigated. Presentation of comprehensive legislation on SHE, covering multiple areas of concern, is relatively new.

There is a need to implement basic policy, rules, regulations and guidelines of legislative framework policies and enforcement of legislation for environmental protection, health improvement, safety, and culture development.

The Punjab Environmental Protection Act, 2012, The Punjab Occupational Safety and Health Act, 2019 and some other international standards have been implemented including ISO-
9000 for quality management, SHE guidelines for successful health and safety management.

Most importantly key business management aspects along with profitability are issues related to occupational health and safety. Employer's commitment is determined by normative acts and standards due to which they cannot be ignored in company management. Safety aspects in business management process are very essential according to efficiency perspective, because unsafe working conditions resulted in possible accidental events that cause material and non-material losses (Górny, 2018). Implementation of human resources management that includes planning, organizing, motivating and controlling cannot take place without paying attention of occupational safety, and health (OSH), (Woźny, Dobosz, \& Saja, 2018).

In modern times, business organizations have become more environmentally oriented to support community, protecting the environment, and concerned about improving the public health. There are many reasons for taking such a move, like institutional pressure, hazardous environment and local community demands. Therefore researchers today put more attention to study the determinants of financial performance in order to understand environmental activity, sustainability practices, health and safety management practices (Chu, Yang, Lee, \& Park, 2017; Walker, Sisto, \& McBain, 2008; Yang, Lau, Lee, Yeung, \& Cheng, 2019; Chen \& Zorigt, 2013; Page, Lamontagne, Louie, Ostry, Shaw, \& Shoveller, 2013; Chuang \& Huang, 2018; Molla, Cooper, \& Pittayachawan, 2011; Villiers \& Sharma, 2017; Foerstl, Reuter, Hartmann, \& Blome, 2010; Annan, Addai, \& Tulashie, 2015; Sarkis, Zhu, \& Lai, 2011)

In developed and emerging economies till date modern research studies have tried their best to investigate the factors that influence environmental, sustainability, health and safety management

${ }^{12}$ UCP Business School, Faculty of Management Studies, UCP, Pakistan. Corresponding author Email: majeed.talha@ucp.edu.pk 
practices. On the other hand, there are limitations existed in results of empirical studies, especially about the role of internal as well as external capabilities. Internal capabilities include intellectual capital, information technology, and entrepreneurial orientation, whereas external capabilities such as government financial support, institutional pressure, and managerial networking in health and safety management practices (Al-Kandari, Al-abdeen, $\&$ Sidhu, 2019). The reason for choosing Glass \& Ceramics and chemical industry is that health and safety management practices plays a vital role in certain industry because it has a major impact on community's health. In addition to this Clark, Crandall and Reynolds, 2019 pointed out that health and safety management practices play pivotal role in every organization, but health and safety management practices are very critical and a need of day in glass \& ceramics and chemical industry.

In Pakistan, business organizations have insufficient resources to achieve task effectively and efficiently. In organizations employees feel satisfied if they are to be provided with good safety climate at workplace. Problems other than safety climate include employee's salary issues and other benefits which employees face in organization other than safety. But most importantly employees are more concerned about safety measurements in an organization. According to Zhuo, Danlong, and Mingrui, (2015) who in their study mention five factors that cause accidents at workplace. These factors include occupational safety and health management, basic source cause, symptoms, contact and loss. There are also other causes of industry's accidents that includes demographic and organizational factors, conditions and work equipment, hazardous acts, time and place, health, safety, environmental training and their control measures. According to Singh and Pant, 2018 and Stellmen, 1998 industries are to be provided with control methods that can reduce and control the environmental hazards and stresses. This can improve the process quality and can achieve organizational changes which limit the number of random factors affecting the process or change the process to another (Maszke, Dwornicka, \& Ulewicz, 2018).

Machines that are operating now a day in glass \& ceramics are mostly manually operated in which especially ceramics industry young boys and women are involved. They don't have any proper training and awareness of safety measures and do not follow any legislation. Accidents regarding heat pressure, burning of hands, working without proper gloves and safety measures are more common in glass \& ceramics industry. Silica dust is the most common existing hazards encountered by ceramics industry. Asbestos found in tile becomes hazardous for workers at workplace. Silica dust is the main pollutant raw material in ceramics industry. Crystalline silica is the most widely found minerals of earth that are carcinogenic in humans.

Occupational heavy metal toxicity is still a major health issue in industries of different countries which use lead based raw materials that may expose to health risks in workers (Maaboud, Mohamed, Gearge, \& Ez-Eldine, 2015). Workers face different types of health hazards in factories that include respirator hazards, toxicity, and exposure to noise, accidents cardiovascular hazards and stress. Pulmonary diseases are more common health issue in tile industry which causes absence from work and early retirement from work (Environmental Health \& Safety Guidelines, 2013). Occupational environmental health and safety problems in workers are increasing day by day due to the negligence of employers (Zivkovic, Vukadinovic, \& Veljkovic, 2018). As employers responsibility to provide good environment and health and safety to workers they are not feeling any responsibility towards the workers' health, they are interested in only their own benefit and to work done (Awan, 2002).

It is a challenging task to analyze how long any individual system can be used without any loss of repression to maximize in service time, as a result to shorten the cost of asset management. In service time of most equipment during design phase exceeds their assigned time (Milazzo \& Bragatto, 2019). Such extensions become helpful because inspection techniques and maintenance procedures gradually improved during last years. However, it is essential to question how long an operator can extend the lifetime of an element without putting at risk the safety of plant. Process equipment includes primary repression systems like atmospheric tanks, pressurized vessels, whereas machinery includes pumps, compressors, along with control and safety systems. It has to be differentiate that aged machine should be replaced along with an out of date system, whereas, large process equipment maybe not viable as it increases costs and have impact on other activities also (Elwany \& N.Z, 2008; Jardine, Lin, \& Banjevic, 2006; Wang \& Hussian, 2009).

The importance of this study and its theoretical contribution and practical implication has multiple advantages. Firstly, it observes the relationship between internal factors such as intellectual capital, ITC, and entrepreneurial orientation, and secondly the external capabilities like government financial support, institutional pressure, managerial networking and health and safety management practices.

\section{Problem statement}

A large number of firms in Pakistan are noncompliance of governance guideline especially in Safety, Health and Environment (SHE) and therefore the present study will take as SHE as its basis to investigate the future issues in the industrial sector of Pakistan more specifically the issue of machines and system eroding, as a threat to future safety and health of both the labor force as well as the firm viability itself. According to modern researchers' effective management actions plays a vital role in worker's perception of safety climate at workplace. Occupational health and safety environment is the most important dilemma faced by every organization now a day (Aziz, Baruji, Abdullah, Him, \& Yusof, 2015) . It influences injuries, accidents and diseases related to industrial work can be observed through analytical kinds of research. Results of these studies show that safety climate becomes pivotal to reduce such incidences. Connection between work safety climate and work-related diseases or injuries have positive outcome on workers' life and his satisfaction level. Safety climate impacts a positive behavior on employees and their performance at workplace (Wang, Sun, Du, \& Wang, 2018). 


\section{Objective of the study}

To analyze the impact of safety issues in relation to the life of machines and systems eroding in Glass \& Ceramics and Chemical industry of Pakistan.

\section{Underpinning Theory}

Accident Theory that Ties Safety and Productivity together, states "In occupational health and safety (OHS) management, it is caused by the presence of hazards that may trigger harmful consequences such as personal injury or property/environmental damage. The probability of this occurring is the risk associated with it" (EHS Today, 2019). The theory of OHS emphasizes that as systems degrade the threat to safety and health magnifies.

\section{Literature Review \\ Empirical Studies}

Goals of ILO on SHE is: "Social justice, fundamental rights at work, the defense and expansion of social protection, full employment and equality are the overarching goals of the ILO and are encapsulated in the concept of "Decent Work". ACTRAV contributes to the attainment of these objectives by supporting trade union activities in a wide range of fields" (Kirby, 2004).

"Incorrect organization of the production environment in the enterprise is the cause of many disruptions during the implementation of production processes (Onyusheva, 2017; Ingaldi, Dziuba, \& Cierniak-Emerych, 2018)".

"According to the WSHI, 2017 more than 2.78 million people die each year globally due to workplace injuries and accidents. Additionally, there are some 374 million nonfatal work-related injuries and illnesses each year. Many of these resulted in extended absences from work due to unsafe or unhealthy workplace conditions (WSHI, 2017)

"Nowadays environment, health and safety (EHS) is most important department in all industries and much progress in developed countries but developing countries like Pakistan still lag behind in this area. Effective EHS management results environmental and resource protection, performance and quality evaluation and minimize risks. Basically, environment, health and safety are measurement, judgment and control of issues that have adverse effect on the health of people at working area. Environment is direct interaction of human with surrounding and Health and safety between the workers and workplaces. Evaluation of EHS is an important tool to find gaps, weakness and suggest mitigation measures accordingly (Li, Liang, Zhang, \& Tang, 2015)". Empirical studies have acknowledged many components that are associated with work related safety and health (Hofmann, Burke, \& Zohar, 2017).

According to (Fitchett, 2018) who examined safety climate in organizations states, safety climate is essential for every organization whose core objective is to enhance employee satisfaction. Modern research elaborates that safety environment refers to employee's awareness about the workplace environment at what level organization is working. There are three dimensions of safety climate including employee's attention, safety supervision and environment (Wang K. , 2018).

Safety climate elaborates safety outcomes which occur at workplace and are related to organizational work, these are work related diseases, accidents and injuries. Hypothetical basics of safety climate discover how to build and apply different levels of analysis. Sense making, motivation and work behavior are some examples that safety climate influences. Major industrial accidents and diseases are caused due to dangerous and hazardous behaviors at workplace. It is also studied in different researches that safety climate could influence behaviors. Safety actions and behaviors belongs to individuals, whereas, safety climate belongs to organizational level (Wang, Sun, Du, \& Wang, 2018).

According to Chen, McCabe and Perlman, (2017) employee's performance becomes high at workplace where they feel they have a safe working environment. In addition to their studies they pointed out that an organization can sustain their high performance by providing equal environment and safety climate to employees. Muhammad (2015) in his study examined that job satisfaction affects notably on-job performance in an organization. According to Kappagoda (2014), employee's performance in the organization can play a pivotal role to meet and achieve organizational goals (Wang, Wang, \& Xia, 2015) . Because in any organization employee performance is a major concept which directly influence organizational work needs to be said (Arvey \& Murphy, 1998).

According to empirical researches about safety environment, those workers who are working in industries where the rate of risk and environment is more hazardous in nature like cloth, fabric, cement, chemical, electrical. Oil \& gas industry suffer more rate of occupational related accidents and diseases to employees like lung cancer, headache, stress, and face and eyes allergies (Aziz, Baruji, Abdullah, Him, \& Yusof, 2017).

In modern times, industries face issues on routines relating to health and safety environments, therefore there is a need to essentially make an organized and stronger health and safety system (Roche, 2017). There are number of legislative frameworks implemented to reduce or avoid occupational accidents related to technical and legal basis. On the other hand, occupational accidents rate is going up (Bergman, Payne, Taylor, \& Beus, 2016).

In ceramics industry most commonly hazardous element to contact with in working environment is silica dust, total dust and heat pressure. Silica dust is the main pollutant in ceramics industry as it is the part of a material which is abundantly available on earth with wide contact in working and ambient environment that affects carcinogenic in humans. Table 1 (See annexure).

Pittiglio, Bragatto and Site, (2014) examined and discussed the limits of generic malfunction rate in public domain that are commonly used by industrial practitioners. This creates that estimates are affected by high uncertainty (Milazzo \& Aven, 2012). On the other hand, different inspection techniques and frameworks are not up to standard that benefited safety procedures, including risk assessment, training and personnel resources, operating control and management changes. In repression systems mostly failures associated with mechanical strength of the structure, which cause leakage of hazardous materials, ultimately, rising severe accidents (OECD, 2017; Palazzi, Caviglione, Reverberi, \& B, 2017; Wood, Arellano, \& Wijk, 2013).

Tile is usually flat hard clay or some other material that extracted from earth to make covering walls, floors. Minerals used are a 
natural material such as feldspar that is used to lower the firing temperature, and chemical additives required for the shaping process (Wadho, 2012).

Hazardous materials are found in tiles material such as cadmium, lead copper, arsenic, iron zinc and traces of other elements. Two most rich elements found in tiles are led and cadmium. Occupational heavy toxicity is still a major health problem in most countries of the world such as Egypt and Turkey. Moreover, lots of industries used lead based raw material to manufacture that exposes health problems in workers (Maaboud, Mohamed, Gearge, \& Ez-Eldine, 2015).

Health hazards among workers in tile industry links to toxicity and exposure to hazardous materials. These hazards include toxicity, exposure to noise, accidents, cardiovascular hazards and stress. Pulmonary diseases in tile industry are among the major disease which cause absence from work and early retirement of worker in working population. These diseases can cause 14\% of workday loss among workers (Environmental Health \& Safety Guidelines, 2013).

At industrial workplaces noise becomes the most common physical hazard. According to European Union report of noise hazard is that $28 \%$ of workers are exposed to noise level between 85 and 90 Decibel Acoustic (dBA). Major health problem caused by noise is to noise induced hearing loss (NIHL), an irreversible but avoidable disorder. NIHL is the second most common form of hearing loss after presbycusis. Tile industry frequently observes machinery, equipment, and tools hazardous noise which makes it more complex for workers and hazardous at workplace (Mostaghaci, R. Kinyua, \& Mugambi, 2013).

According to Alim, Biswas and Hossain, (2014) study respiratory health problems among ceramic workers in Dhaka showed that most respiratory problems occur among workers due to high amount of ceramic and tile dust particles at workplace. According to their study other potential environmental confounding factors could not be ignored from the analysis.

According to Kheni, Gibb and Dainty, (2010), 5\% accidents on construction sites in Ghana are deadly in nature. Condition of safety, health and environment (SHE), in Ghanaian construction industry is very poor (Laryea \& Mensah, 2010; Ametepey \& Ansah, 2014).

Poor performance happens due to lack of management control and lack of priority to safety and environmental considerations in delivery of building projects, other factors include inefficient institutional and legal framework and carelessness in enforcing of existing SHE regulations, all of this shows a poor SHE management culture (Kheni, Gibb, \& Dainty, 2010; Ametepey \& Ansah, 2014).

\section{Research Methodology}

This research paper examined chemical and glass \& ceramic sectors of Pakistan. Data used is derived from balance sheet analysis of thirty-four PSX listed firms. This research uses quantitative research technique in which numeric databases are used in order to derive meanings from numbers (Aliaga \& Gunderson, 2004). According to Saunders, Lewis, and Thornhill (2009) quantitative research is mostly used as a synonym for any kind of data collection technique. Sample of thirty-four firms was selected. Secondary data was employed for a period of seven years from 2012 to 2018.

Table 2 (See annexure).

Limitations of the Study

1. Study data ranges from 2012 - 2018, as there was unavailability of data before 2012 .

2. Researcher took Glass \& Ceramics and Chemical industry; because they involve more hazardous elements at workplace and condition of, SHE becomes more critical for workers.

3. Sample of 34 industrial firms becomes the limitation, as they are from two sectors of economy namely glass \& ceramics and chemical industry of Pakistan.

\section{Discussion}

As already mentioned, health and safety are important from two aspects. On one side the buyers of the product want to ensure, at least on the international market that processes involving the production of the product were environmentally friendly, labor laws were abided by and safety and health of the work force were ensured. On the other hand, it is important to reduce litigation or strikes by the labor unions are minimized because that impacts upon the reputation of the firm, the workability of the labor force as well as on the costs of production in one way or the other.

Most of the firms under review have on their websites tried to build a profile that they are environmentally friendly and abide by the principles of (SHE) and good governance. Also, the laws of the land have ample legal frameworks to support the implementation of (SHE) and in-house safety measures. But it is noted that the implementation of laws of the land by firms especially those that are not multinational or do not sell their produce output abide, is not up to the desired standards although national quality standards exists in Pakistan. They are rarely implemented or abided by/enforced.

One of the arguments given by firms of not abiding by (SHE) principles absolutely is that the macroeconomic environment is not favorable to their cost cutting techniques. This is an infant industry argument which cannot be bought by researchers today because of WTO implementation rules as well as because of the principle of efficient management in a firm which leads to better comparative profit and brand names for their firms.

\section{Outcome of the Research}

Organizations success is hidden under the umbrella of several factors that plays significant role. Past several decades are witnessed that researchers and academia have shown interest in the study to explore factors that considerably add to organization's success and performance. On the other hand, in this scenario employees are main players who supposed to be the most significant analysts. As well as this employee will not perform better until they feel safe and pleased about the workplace environment.

The present research concludes that as systems and machines degrade in an organization/firm over time. The threat to safety and health of the work force is compromised and therefore machines and systems should be upgraded regularly, even when they increase costs and tend to reduce profit margins for any firm to mitigate both safety issues as well as costly litigations linked to these issues. 


\section{References}

Alim, M., Biswas, M., \& Hossain, M. (2014). Respiratory health problems among the ceramic workers in Dhaka- Bangladesh. Farridpur Medical College Journal, 9, 19-23.

Al-Kandari, D., Al-abdeen, J., \& Sidhu, J. (2019). Food safety knowledge, attitudes and practices of food handlers in restaurants in Kuwait. Food Control, 103, 103-110.

Ametepey, S., \& Ansah, S. (2014). Impacts of construction activities on the environment: The case of Ghana. Journal of Construction Project Management and Innovation, 934-948.

Anderson, J., \& Rainie, L. (2018, December 10). Solutions to address AI's anticipated negative impacts. Retrieved from Pew Research center: https://www.pewresearch.org/internet/2018/12/10/solutions-toaddress-ais-anticipated-negative-impacts/

Annan, J. S., Addai, E., \& Tulashie, S. (2015). A call for action to improve occupational health and safety in Ghana and a critical look at the existing legal requirement and legislation. Safety Health Work, 6, 146-150.

Awan, S. (2002). The Development of trends of occupational health and safety services in Pakistan. unpublished Report, Islamabad, Pakistan .

Aziz, A. A., Baruji, M., Abdullah, M., Him, N., \& Yusof, N. (2015). An initial study on accident rate in the workplace through occupational safety and health management in sewerage services. International Journal of Business and Social Science, 6 (2), 29-255.

Bergman, M., Payne, S., Taylor, A., \& Beus, J. (2016). "The shelf life of a safety climate assessment: How long until the relationship with safety-critical incidents expires. Journal of Business Psychology, 29, 519-540.

Chen, J., \& Zorigt, D. (2013). Managing occupational health and safety in the mining industry. J. Bus. Res, 66, 2321-2331.

Chen, Y., McCabe, B., \& Perlman, D. (2017). Impact of individual resilience and safety climate on safety performance and psychological stress of construction workers: A case study of the Ontario construction industry. Journal of safety Research, 61, 167-176.

Chu, S., Yang, H., Lee, M., \& Park, S. (2017). The impact of institutional pressures on green supply chain management and firm performance: Top management roles and social capital. Sustainability, 9, 764 .

Chuang, S. P., \& Huang, S. (2018). The effect of environmental corporate social responsibility on environmental performance and business competitiveness: The mediation of green information technology capital. Journal of Business Ethics, 150, 991-1009.

Clark., J., Crandall, P., \& Reynolds, J. (2019). Exploring the influence of food safety climate indicators on handwashing practices of restaurant food handlers. Int. J. Hosp. Manag, 77, 187-194.

EHS Today. (2019, December 26). An Accident Theory that Ties Safety and Productivity Together. Retrieved from EHS Today: https://www.ehstoday.com/archive/article/21907594/anaccident-theory-that-ties-safety-and-productivity-together
Environmental Health \& Safety Guidelines. (2013). Ceramic Tile and Sanitary Ware Manufacturing.

Fitchett, P. (2018). Searching for satisfaction: Black female teachers' workplace climate and job satisfaction. Urban Education, 53 (1), 86-112.

Foerstl, K., Reuter, C., Hartmann, E., \& Blome, C. (2010). Managing supplier sustainability risks in a dynamically changing environment-Sustainable supplier management in the chemical industry. Journal of Purchase and Supply Chain Management, 16, 118-130.

Górny, A. (2018). Safety in ensuring the quality of production the role and tasks of standards requirements. MATEC Web Conf. 183 , 01005 . doi:https://doi.org/10.1051/matecconf/201818301005

Hofmann, D. A., Burke, M., \& Zohar, D. (2017). 100 years of occupational safety research: From basic protections and work analysis to a multilevel view of workplace safety and risk. Journal of Applied Psychology, 102 (3), 375-388.

Hull, T. (2019, October). Improving automation safety with selftaught industrial machines, robots. Retrieved from AI and Machine

Learning: https://www.controleng.com/articles/improving-automationsafety-with-self-taught-industrial-machines-robots/

Ingaldi, M., Dziuba, S., \& Cierniak-Emerych, A. (2018). Analysis of problems during implementation of Lean Manufacturing elements. MATEC Web Conf. 183, 01004. doi:https://doi.org/10.1051/matecconf/201818301004

International Labor Organization (ILO). (2019). SAFETY AND HEALTH AT THE HEART OF THE FUTURE OF WORK Building on 100 years of Experience. Retrieved from International Labor Organization (ILO): https://www.ilo.org/wcmsp5/groups/public/---dgreports/--dcomm/documents/publication/wcms_686645.pdf

Kappagoda, S., Othman, H., \& Alwis, G. D. (2014). The impact of psychological capital on job performance: Development of a conceptual framework. European Journal of Business and Management, 6 (14), 14-315.

Kavanagh, C. (2019, August 28). New Tech, New Threats, and New Governance Challenges: An Opportunity to Craft Smarter Responses? Retrieved from Carnegie Endowment for International Peace: https://carnegieendowment.org/2019/08/28/new-tech-newthreats-and-new-governance-challenges-opportunity-to-craftsmarter-responses-pub-79736

Kheni, N., Gibb, A., \& Dainty, A. (2010). Health and safety management in developing countries: A study of construction SMEs in Ghana. Construction Management and Economics, 26 (11), 1159-1169.

Kirby, P. H. (2004). ILO Guidelines on Safety, Health and Environmnet . Retrieved from Trade Union Manual as Guidelines for Agricultural Workers: https://www.ilo.org/wcmsp5/groups/public/---ed_protect/--protrav/---

safework/documents/instructionalmaterial/wcms_110199.pdf

Laryea, S., \& Mensah, S. (2010). Health and safety on construction sites in Ghana. COBRA. Dauphin Université, Paris , 2-3. 
Li, W., Liang, W., Zhang, L., \& Tang, Q. (2015). Performance assessment system of health, safety and environment based on experts' weights and fuzzy comprehensive evaluation. Journal of Loss Prevention in the Process Industries, 35, 95-103.

Maaboud, A. E., Mohamed, Z., Gearge, S., \& Ez-Eldine, A. (2015). Lead and cadmium toxicity in tile manufacturing workers at assiut, Egypt. Arab Journal of Forensic Sciences and Forensic Medicine, 1 (29), 299-311.

Maszke, A., Dwornicka, R., \& Ulewicz, R. (2018). Problems in the Implementation of the lean concept at a steel works - Case study. MATEC Web Conf. 183, 01014. doi:https://doi.org/10.1051/matecconf/201818301014

Milazzo, M., \& Aven, T. (2012). An extended risk assessment approach for chemical plants applied to a study related to pipe ruptures. Reliability Engineering \& System Safety, 99, 183-192.

Milazzo, M., \& Bragatto, P. (2019). A framework addressing a safe ageing management in complex industrial sites: The Italian experience in «Seveso» establishments. Journal of Loss Prevention in the Process Industries, 58, 70-81.

Molla, A., Cooper, V., \& Pittayachawan, S. (2011). The green IT readiness (G-Readiness) of organizations: An exploratory Analysis of a construct and instrument. Communication, Association, Information System, 29, 67-96.

Mostaghaci, R. Kinyua, R., \& Mugambi, F. (2013). Health effects of lead exposure among Jua Kali workers in Mombasa, Kenya. International Journal of Medicine and Medical Sciences, 5, 2429.

Muhammad, M. (2015). The influence of competence, motivation, and organizational culture to high school teacher job satisfaction and performance. International Education Studies, 8 (1), 38-45.

OECD. (2017). Ageing of hazardous installations. OECD Environment, Health and Safety Publications - Series on Chemical Accidents no. 29

Onyusheva, I. (2017). Analytical and managerial issues of human capital in conditions of global competitiveness: The case of Kazakhstan. Polish Journal of Management Studies, 16, 198209. doi:https://doi.org/10.17512/pjms.2017.16.2.17

Page, K., Lamontagne, A., Louie, A., Ostry, A., Shaw, A., \& Shoveller, J. (2013). Stakeholder perceptions of job stress in an industrialized country: Implications for policy and practice. Journal of Public Health Policy, 34, 447-461.

Palazzi, E., Caviglione, C., Reverberi, A., \& B. (2017). A shortcut analytical model of hydrocarbon pool fire of different geometries, with enhanced view factor evaluation. Process Safety and Environmental Protection, 110, 89-101.

Pittiglio, P., Bragatto, P., \& Site, C. D. (2014). Updated failure rates and risk management in process industries. Energy Procedia, 45, 1364-1371.

Roche, M. (2017). Guidelines for the assurance of safety, security, Health and environmental protection, safety behaviour: assessing the mediating role of safety knowledge and motivation. Accident and Prevention Journal. 2010, 42 (6), 2082-93.
Sarkis, J., Zhu, Q., \& Lai, K. (2011). An organizational theoretic review of green supply chain management literature. International Journal of Production Economics, 130, 1-15.

Singh, P., \& Pant, D. (2018). Waste-to-waste management and resource conservation and recycling. Environmental Engineering and Management Journal, 17, 1103-1111.

Stellmen, (. J. (1998). Encyclopedia of Occupational Health and Safety, 4th Edition, International Labour Organizational Publications, Geneva .

The Punjab Environmental Protection Act. (2012). The Punjab Environmental Protection Act, 2012.

The Punjab Occupational Safety and Health Act. (2019). The Punjab Occupational Safety and Health Act, 2019.

Villiers, C. D., \& Sharma, U. (2017). A critical reflection on the future of financial, intellectual capital, sustainability and integrated reporting. Crit. Perspect. Account

Wadho, L. (2012). Civil Engineering Material.

Walker, H., Sisto, L. D., \& McBain, D. (2008). Drivers and barriers to environmental supply chain management practices: Lessons from the public and private sectors. Journal of Purchasing and Supply Management, 14, 69-85.

Wang, D., Wang, X., \& Xia, N. (2015). How safety related stress affects workers' safety behavior: The mediating role of psychological capital. Journal of Safety Science, 103, 247-259.

Wang, K. (2018). Negative impact induced by foreign workers: Evidence in Hong Kong construction sector. Habitat. International Journal of Occupational Safety, 36, 433-443.

Wang, M., Sun, J., Du, H., \& Wang, C. (2018). "Relations between safety climate, awareness, and Behavior in the Chinese Construction Industry: A Hierarchical Linear Investigation. Journal of Advances in Civil Engineering , vol. 2018.

Wood, M., Arellano, A., \& Wijk, L. V. (2013 ). Corrosion related accidents in petroleum refineries. European Commission Joint Research Centre Report no. EUR (2013) .

Woźny, A., Dobosz, M., \& Saja, P. (2018). Budowanie Strategii Zarządzania BHP w Przedsiębiorstwie. Qual. Prod. Improv, 8, 75-83.

WSHI. (2017). Global estimates of occupational accidents and work related illnesses. Workplace Safety and Health Institute, Singapore.

Yang, Y., Lau, A., Lee, P. K., Yeung, A., \& Cheng, T. (2019). Efficacy of China's strategic environmental management in its institutional environment. International Journal of Operations and Production Management, 39, 138-163.

Zhuo, S., Danlong, L., \& Mingrui, L. M. (2015). The Establishment and analylis of accident-controlled model based on three-dimensional coordinates. The Open Automation and Control Systems Journal, 7, 1034.

Zivkovic, S., Vukadinovic, B., \& Veljkovic, M. (2018). Cleaner and energy efficient production: A case study. Environmental Engineering and Management. 
Table 1:

\begin{tabular}{|c|c|c|c|c|c|c|c|c|c|c|c|}
\hline Company & $\begin{array}{l}\text { Ye } \\
\text { ar }\end{array}$ & $\begin{array}{l}\text { Inaugura } \\
\text { ted }\end{array}$ & Machinery Upgraded & $\begin{array}{l}\text { Machinery } \\
\text { Discarded }\end{array}$ & $\begin{array}{l}\text { OSHAS } \\
\text { 18001:2007 }\end{array}$ & $\begin{array}{l}\text { ISO } \\
9001\end{array}$ & $\begin{array}{l}\text { ISO } \\
14001\end{array}$ & $\begin{array}{l}\text { ISO } \\
\text { 1901:2008 }\end{array}$ & $\begin{array}{l}\mathbf{N E} \\
\mathrm{OS}\end{array}$ & $\begin{array}{l}\text { ISO } \\
\text { 22000:2005 }\end{array}$ & $\begin{array}{ll}\text { ISO } \\
9002\end{array}$ \\
\hline \multirow[t]{7}{*}{ Agritech Limited } & 201 & 1959 & No & No & Yes & Yes & Yes & (2) & 2 & 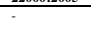 & - \\
\hline & 201 & 1959 & No & No & Yes & Yes & Yes & - & - & - & - \\
\hline & 201 & 1959 & No & No & Yes & Yes & Yes & - & - & - & - \\
\hline & $\begin{array}{l}201 \\
5\end{array}$ & 1959 & No & No & Yes & Yes & Yes & 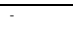 & $=$ & - & - \\
\hline & 201 & 1959 & No & No & Yes & Yes & Yes & - & - & - & - \\
\hline & 201 & 1959 & No & No & Yes & Yes & 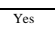 & - & - & - & 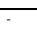 \\
\hline & $\begin{array}{l}201 \\
8\end{array}$ & 1959 & No & No & Yes & Yes & Yes & $=$ & - & - & 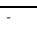 \\
\hline \multirow[t]{7}{*}{ Akzo Nobel Pakistan Limited } & $\begin{array}{ll}201 \\
2\end{array}$ & 2011 & $\begin{array}{l}\text { Foam Sprinkler System, } \\
\text { Compressor }\end{array}$ & No & Yes & Yes & Yes & - & - & 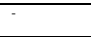 & - \\
\hline & 201 & 2011 & High Efficiency Motors, Water Chiller, Fume Extraction System, Dust Extractor System, 5S, Racking Structure & No & Yes & Yes & Yes & & & & \\
\hline & 201 & 2011 & $\begin{array}{l}\text { Racking structure, Dicsel Generator, Air Operated Pumps, Metering System for Water Supply, Re-use of Rinsing } \\
\text { Water }\end{array}$ & No & 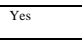 & Yes & 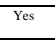 & . & 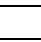 & - & \\
\hline & 201 & 2011 & Thinner Recycling Machines, Bead Mill, Air Cooled Water chiller & No & Yes & Yes & Yes & - & $\cdot$ & $\cdot$ & - \\
\hline & $\begin{array}{l}201 \\
6\end{array}$ & 2011 & LED lights, Waste Reduction Initiative & No & Yes & Yes & Yes & $\overline{-}$ & $=$ & - & \\
\hline & 201 & 2011 & LED lights, Waste Reduction Initiative & No & Yes & Yes & Yes & - & $\overline{-}$ & 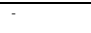 & $\overline{-}$ \\
\hline & $\begin{array}{l}201 \\
8\end{array}$ & 2011 & $\begin{array}{ll}\text { LED lights, Solar Panels Installation } \\
\end{array}$ & No & Yes & Yes & Yes & - & - & - & $\overline{-}$ \\
\hline \multirow[t]{7}{*}{ Achroma Pakistan Limited } & $\frac{201}{2}$ & $\cdot$ & $\cdot$ & - & $\cdot$ & $\cdot$ & - & - & - & - & - \\
\hline & $\begin{array}{ll}201 \\
3\end{array}$ & 2013 & No & No & Yes & Yes & Yes & - & $\overline{-}$ & 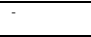 & $=$ \\
\hline & 201 & 2013 & No & No & Yes & Yes & Yes & $=$ & $\bar{c}$ & - & - \\
\hline & 201 & 2013 & No & No & Yes & Yes & Yes & - & - & - & $=$ \\
\hline & $\begin{array}{l}201 \\
6\end{array}$ & 2013 & Clean Water Supply Line, Sustainable Effluent Treatment Plant & No & Yes & Yes & 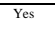 & $=$ & $=$ & $=$ & $=$ \\
\hline & 201 & 2013 & No & No & Yes & Yes & Yes & - & $=$ & - & $\bar{\theta}$ \\
\hline & 201 & 2013 & No & No & Yes & Yes & Yes & - & $=$ & 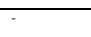 & $\bar{\theta}$ \\
\hline \multirow[t]{7}{*}{ Bawany Air Product Limited } & 201 & 1978 & $25 \mathrm{MT}$ New Plant & No & No & No & No & - & - & - & - \\
\hline & $\begin{array}{l}2 \\
201 \\
3\end{array}$ & 1978 & Plant & No & No & No & No & - & 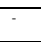 & - & - \\
\hline & 201 & 1978 & No & No & No & No & No & - & - & - & - \\
\hline & $\begin{array}{l}201 \\
5\end{array}$ & 1978 & No & No & No & No & No & 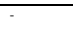 & - & 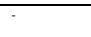 & 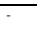 \\
\hline & $\begin{array}{l}201 \\
6\end{array}$ & 1978 & 2 Compressors Overhauling & No & No & No & No & $=$ & $=$ & $=$ & $=$ \\
\hline & 201 & 1978 & No & No & No & No & No & - & $=$ & $\cdot$ & \\
\hline & 201 & 1978 & No & No & No & No & No & 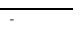 & - & 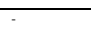 & - \\
\hline \multirow{7}{*}{$\begin{array}{l}\text { Berger Paints Pakistan } \\
\text { Limited }\end{array}$} & 201 & 1950 & No & No & Yes & Yes & Yes & - & - & 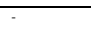 & - \\
\hline & $\begin{array}{l}201 \\
3\end{array}$ & 1950 & No & No & Yes & Yes & Yes & - & - & 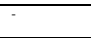 & - \\
\hline & 201 & 1950 & No & No & Yes & Yes & Yes & - & - & - & - \\
\hline & $\begin{array}{l}201 \\
5\end{array}$ & 1950 & No & No & Yes & Yes & Yes & - & - & 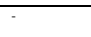 & - \\
\hline & 201 & 1950 & No & No & Yes & Yes & Yes & 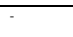 & - & 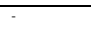 & 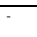 \\
\hline & $\begin{array}{l}201 \\
7\end{array}$ & 1950 & No & No & Yes & Yes & Yes & $=$ & $=$ & $=$ & $=$ \\
\hline & $\begin{array}{l}201 \\
8\end{array}$ & 1950 & Capacity Increase, Toll Manufacturing, Oxyplast, New Godown & No & Yes & Yes & Yes & - & $\overline{-}$ & $=$ & $\overline{-}$ \\
\hline \multirow[t]{7}{*}{ Baifo Industries Limited } & $\begin{array}{l}201 \\
2\end{array}$ & 1988 & No & No & Yes & $\overline{-}$ & - & Yes & - & $\overline{-}$ & 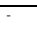 \\
\hline & 201 & 1988 & No & No & Yes & - & - & Yes & - & - & - \\
\hline & $\begin{array}{l}201 \\
4\end{array}$ & 1988 & No & No & Yes & $=$ & - & Yes & - & $=$ & - \\
\hline & $\begin{array}{l}201 \\
5\end{array}$ & 1988 & New Projects & No & Yes & - & 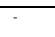 & Yes & 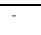 & - & - \\
\hline & 201 & 1988 & No & No & Yes & $=$ & $=$ & Yes & - & $=$ & 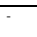 \\
\hline & $\begin{array}{l}6 \\
201 \\
7\end{array}$ & 1988 & No & No & Yes & 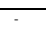 & $=$ & Yes & 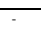 & $=$ & - \\
\hline & $\begin{array}{l}201 \\
8\end{array}$ & 1988 & No & No & Yes & $=$ & $=$ & Yes & $=$ & $=$ & $=$ \\
\hline \multirow[t]{7}{*}{ Buxly Paints Limited } & 201 & 1954 & No & No & No & No & No & - & - & - & - \\
\hline & 201 & 1954 & No & No & No & No & No & 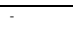 & - & $=$ & - \\
\hline & 201 & 1954 & No & No & No & No & No & - & - & - & - \\
\hline & $\begin{array}{l}201 \\
5\end{array}$ & 1954 & No & No & No & No & No & - & - & - & - \\
\hline & 201 & 1954 & No & No & No & No & No & - & 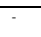 & - & - \\
\hline & $\begin{array}{l}6 \\
201 \\
7\end{array}$ & 1954 & No & No & No & No & No & - & - & - & 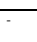 \\
\hline & $\begin{array}{l}201 \\
8\end{array}$ & 1954 & No & No & No & No & No & - & - & - & - \\
\hline \multirow{7}{*}{$\begin{array}{l}\text { Colgate Palmolive (Pakistan } \\
\text { Limited) }\end{array}$} & $\begin{array}{l}201 \\
2\end{array}$ & 1977 & No & No & No & No & No & - & - & - & - \\
\hline & 201 & 1977 & No & No & No & No & No & - & - & - & - \\
\hline & $\begin{array}{l}201 \\
4\end{array}$ & 1977 & No & No & No & No & No & - & - & - & - \\
\hline & 201 & 1977 & No & No & No & No & No & - & - & - & - \\
\hline & $\begin{array}{l}201 \\
6\end{array}$ & 1977 & No & No & No & No & No & 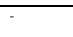 & 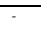 & 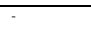 & 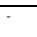 \\
\hline & 201 & 1977 & No & No & No & No & No & $=$ & $=$ & $=$ & 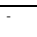 \\
\hline & $\begin{array}{l}201 \\
8\end{array}$ & 1977 & No & No & No & No & No & - & - & $\cdot$ & - \\
\hline \multirow[t]{7}{*}{ Data Agro Limited } & 201 & 1992 & No & No & No & No & No & - & $=$ & $=$ & - \\
\hline & 201 & 1992 & No & No & No & No & No & 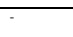 & 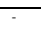 & 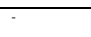 & 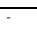 \\
\hline & $\begin{array}{l}201 \\
4\end{array}$ & 1992 & No & No & No & No & No & - & - & - & - \\
\hline & $\begin{array}{l}201 \\
201\end{array}$ & 1992 & No & No & No & No & No & - & - & 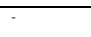 & - \\
\hline & 201 & 1992 & No & No & No & No & No & - & - & 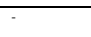 & - \\
\hline & 201 & 1992 & No & No & No & No & No & $\theta$ & - & 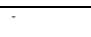 & - \\
\hline & $\begin{array}{l}201 \\
8\end{array}$ & 1992 & No & No & No & No & No & 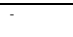 & $=$ & 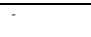 & 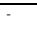 \\
\hline Descon Oxychem Limited & $\begin{array}{l}201 \\
2\end{array}$ & 2004 & No & No & $=$ & $=$ & $=$ & $=$ & Yes & $=$ & $=$ \\
\hline
\end{tabular}




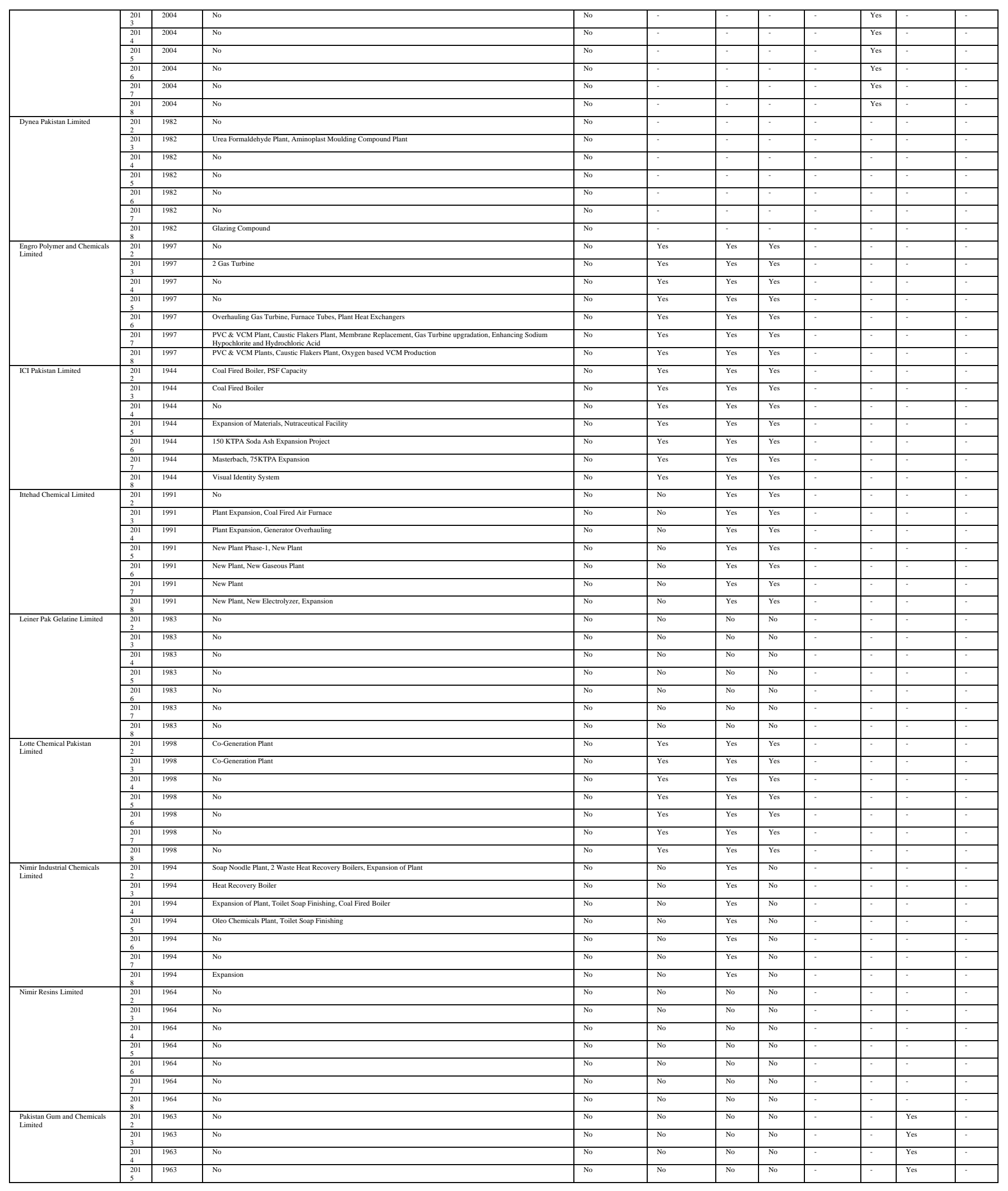




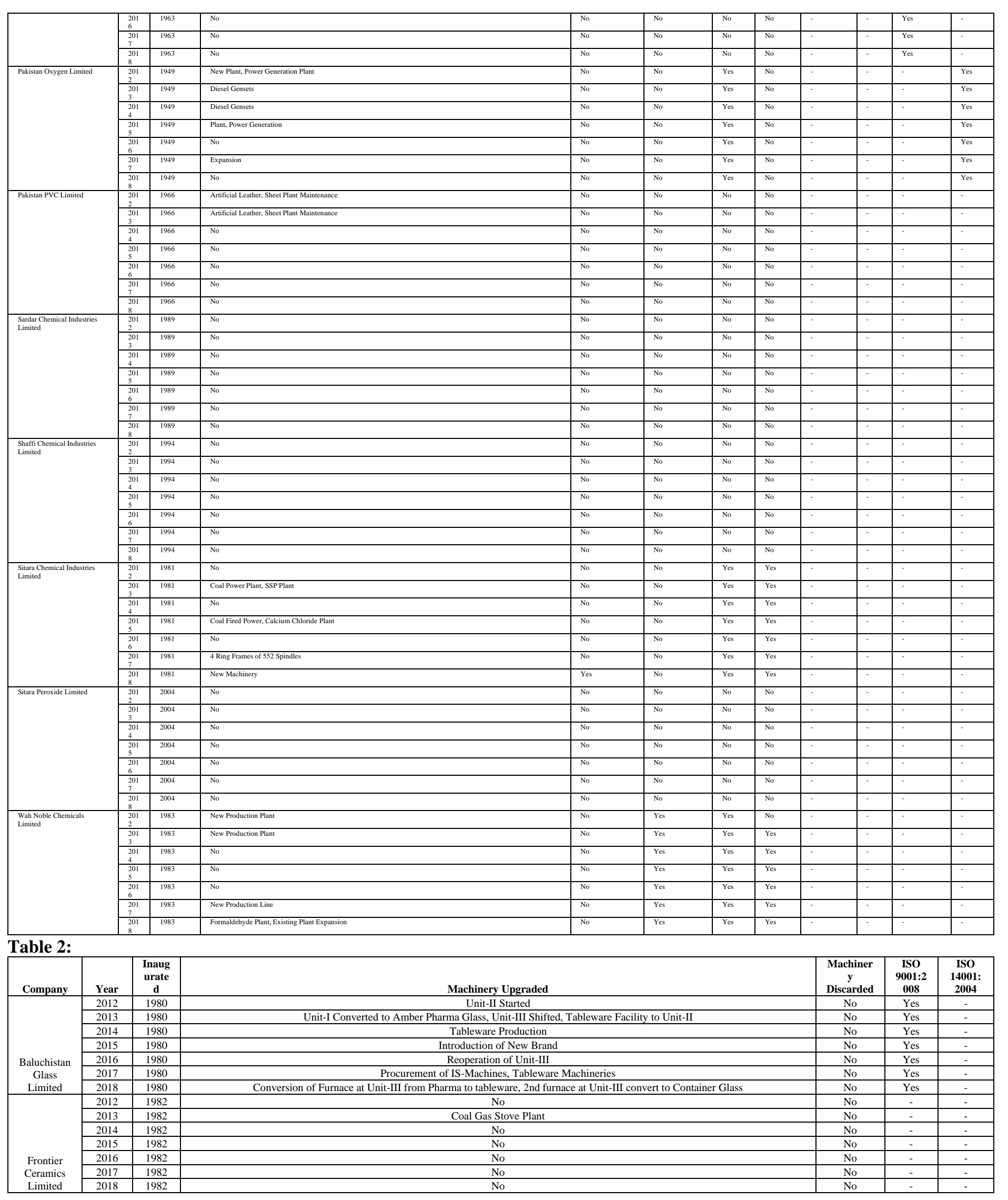




\begin{tabular}{|c|c|c|c|c|c|c|}
\hline \multirow{7}{*}{$\begin{array}{l}\text { Ghani Glass } \\
\text { Limited }\end{array}$} & 2012 & 1992 & Float Glass Project & No & Yes & Yes \\
\hline & 2013 & 1992 & Container Glass Furnace & No & Yes & Yes \\
\hline & 2014 & 1992 & No & No & Yes & Yes \\
\hline & 2015 & 1992 & Ambar Pharma Glass Furnace, Expansion of Float Glass Production & No & Yes & Yes \\
\hline & 2016 & 1992 & No & No & Yes & Yes \\
\hline & 2017 & 1992 & $\begin{array}{l}\text { Float Line } \\
\end{array}$ & No & Yes & Yes \\
\hline & 2018 & 1992 & Float Line 1, Expansion, Rebuilt food \& Beverage furnace, Pharma Furnace & No & Yes & Yes \\
\hline \multirow{7}{*}{$\begin{array}{c}\text { Ghani } \\
\text { Global } \\
\text { Glass } \\
\text { Limited } \\
\end{array}$} & 2012 & 2007 & New Plant & No & Yes & Yes \\
\hline & 2013 & 2007 & No & No & Yes & Yes \\
\hline & 2014 & 2007 & ASU Plant & No & Yes & Yes \\
\hline & 2015 & 2007 & Installing 2 Cummins Diesel Generator at GGL-1, 3-Vacuum Industrial Storage Tanks, Forced Injection System at GGL-I \& II & No & Yes & Yes \\
\hline & 2016 & 2007 & $\begin{array}{l}\text { 2- Vacuum Insulated Industrial Storage Tanks, Forced Liquid Injection System at GGL-I \& II, ASU Plant GGL-I \& GGL-II upgraded, } \\
\text { Upgraded Air Compressors, Water Supply Connection from KW\&SB for GGL-II, New ASU Plant Port Qasim, Calcium Carbide } \\
\text { Manufacturing Plant, }\end{array}$ & No & Yes & Yes \\
\hline & 2017 & 2007 & Air Supply to ASU Plant GGL-I \&GGL-II, Air Compressors & No & Yes & Yes \\
\hline & 2018 & 2007 & Power House Control System Upgraded, Compressed Facility at Tarnol & No & Yes & Yes \\
\hline \multirow{7}{*}{$\begin{array}{l}\text { Ghani } \\
\text { Value Glass } \\
\text { Limited }\end{array}$} & 2012 & 1967 & Double Glazing Line, Aluminum Coating Line & No & Yes & No \\
\hline & 2013 & 1967 & No & No & Yes & No \\
\hline & 2014 & 1967 & No & No & Yes & No \\
\hline & 2015 & 1967 & Induction of High Tech Plant & No & Yes & No \\
\hline & 2016 & 1967 & No & No & Yes & No \\
\hline & 2017 & 1967 & No & No & Yes & No \\
\hline & 2018 & 1967 & Lamination, Autoclave, Double Glazed, Double Edging, Sandblasting, Beveling Glass Lines & No & Yes & No \\
\hline \multirow{7}{*}{$\begin{array}{c}\text { Karam } \\
\text { Ceramics } \\
\text { Limited }\end{array}$} & 2012 & 1979 & No & No & No & No \\
\hline & 2013 & 1979 & No & No & No & No \\
\hline & 2014 & 1979 & No & No & No & No \\
\hline & 2015 & 1979 & New Plant \& Machinery & No & No & No \\
\hline & 2016 & 1979 & New Size of Tiles & No & No & No \\
\hline & 2017 & 1979 & No & No & No & No \\
\hline & 2018 & 1979 & No & No & No & No \\
\hline \multirow{7}{*}{$\begin{array}{c}\text { Shabbir } \\
\text { Tiles \& } \\
\text { Ceramics } \\
\text { Limited }\end{array}$} & 2012 & 1978 & No & No & No & No \\
\hline & 2013 & 1978 & No & No & No & No \\
\hline & 2014 & 1978 & No & No & No & No \\
\hline & 2015 & 1978 & No & No & No & No \\
\hline & 2016 & 1978 & New Size \& Design & No & No & No \\
\hline & 2017 & 1978 & Modernization of Plant \& Machinery & No & No & No \\
\hline & 2018 & 1978 & No & No & No & No \\
\hline \multirow{7}{*}{$\begin{array}{l}\text { Tariq Glass } \\
\text { Industries } \\
\text { Limited }\end{array}$} & 2012 & 1978 & Float Glass Project & No & No & No \\
\hline & 2013 & 1978 & No & No & No & No \\
\hline & 2014 & 1978 & Rebuilding of Tableware Producing Furnace & No & No & No \\
\hline & 2015 & 1978 & No & No & No & No \\
\hline & 2016 & 1978 & $\begin{array}{l}\text { Jug Making Machine, Toughening Lehr for Light Weight Tempered Plates \& Bowls Useable in Microwave Owen, Float glass colors, } \\
\text { Mirror \& Sand blasted Float Glass manufactured, }\end{array}$ & No & No & No \\
\hline & 2017 & 1978 & Opal Glass Dinnerware & No & No & No \\
\hline & 2018 & 1978 & ROCKWARE, Float Glass Plant Unit-II & No & No & No \\
\hline
\end{tabular}

